\title{
Actin filaments altered distribution in wheat (Triticum aestivum) "Bending Root" to respond to enhanced Ultraviolet-B radiation
}

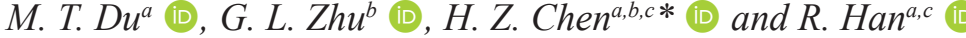 \\ aShanxi Normal University, Higher Education Key Laboratory of Plant Molecular and Environment Stress Response, \\ Linfen, Shanxi, China \\ ${ }^{b}$ Ministry of Education of China, Yangzhou University, Joint International Research Laboratory of Agriculture and Agri- \\ Product Safety, Yangzhou, Jiangsu, China \\ 'Shanxi Normal University, School of Life Science, Linfen, Shanxi, China \\ *e-mail: chenhuize@hotmail.com
}

Received: October 9, 2019 - Accepted: March 28, 2020 - Distributed: August 31, 2021

(With 6 figures)

\begin{abstract}
Plants adjust their shoot growth to acclimate to changing environmental factors, such as to enhanced Ultraviolet-B (UV-B) radiation. However, people have ignored that plant roots can also respond to UV-B light. Here, we find the morphology curled wheat roots under UV-B radiation, that we call, "bending roots." The curly region is the transition zone of the root after observed at the cellular level. After exposed to enhanced UV-B radiation for $2 \mathrm{~d}\left(10.08 \mathrm{KJ} / \mathrm{m}^{2} / \mathrm{d}\right)$, cell size decreased and actin filaments gathered in wheat roots. We also find that $\mathrm{H}_{2} \mathrm{O}_{2}$ production increased and that content of the indole-3-acetic acid (IAA) increased remarkably. The pharmacological experiment revealed that actin filaments gathered and polymerized into bundles in the wheat root cells after irrigated $\mathrm{H}_{2} \mathrm{O}_{2}$ and IAA. These results indicated that actin filaments changed their distribution and formed the "bending root," which was related to $\mathrm{H}_{2} \mathrm{O}_{2}$ production and increase in IAA. Overall, actin filaments in wheat root cells could be a subcellular target of UV-B radiation, and its disruption determines root morphology.
\end{abstract}

Keywords: UV-B radiation, actin dynamics, wheat, root morphogenesis.

\section{Distribuição alterada dos filamentos de actina no trigo (Triticum aestivum) "Raiz dobrada" para responder à radiação ultravioleta $B$ aprimorada}

\begin{abstract}
Resumo
As plantas ajustam o crescimento da parte aérea para se adaptarem a fatores ambientais variáveis, como o aumento da radiação ultravioleta $\mathrm{B}$ (UVB). No entanto, as pessoas ignoram que as raízes das plantas também podem responder à luz UVB. Neste estudo, verificamos a morfologia das raízes enroladas de trigo sob radiação UVB, o que chamamos de "raízes dobradas". A região encaracolada é a zona de transição da raiz no nível celular. Depois de exposição à radiação UVB aprimorada por 2 dias $\left(10,08 \mathrm{KJ} / \mathrm{m}^{2} / \mathrm{d}\right)$, o tamanho das células diminuiu, e os filamentos de actina se reuniram. Também constatamos que a produção de $\mathrm{H}_{2} \mathrm{O}_{2}$ aumentou e que o conteúdo do ácido indol-3-acético (IAA) aumentou notavelmente. $\mathrm{O}$ experimento farmacológico revelou que os filamentos de actina se reuniram e polimerizaram em feixes nas células da raiz de trigo após irrigação com $\mathrm{H}_{2} \mathrm{O}_{2}$ e IAA. Esses resultados indicam que os filamentos de actina alteraram sua distribuição e formaram a "raiz dobrada", relacionada à produção de $\mathrm{H}_{2} \mathrm{O}_{2}$ e ao aumento do IAA. No geral, os filamentos de actina nas células da raiz de trigo podem ser um alvo subcelular da radiação UVB, e sua interrupção determina a morfologia da raiz.
\end{abstract}

Palavras-chave: UVB aprimorado, dinâmica de actina, trigo, morfogênese radicular.

\section{Introduction}

Ultraviolet-B (UV-B) radiation is a regular component of sunlight, which has a significant effect on lives (Jenkins, 2017). Almost $95 \%$ of UV-B radiation is absorbed by stratospheric ozone, but transmitted UV-B affects plant growth and development significantly (Brosche and Strid, 2003). With the decreasing of ozone and activating atmospheric circulation, transmitted UV-B radiation is increasing. Enhanced UV-B radiation damages cells' nucleic acid and plasma membranes. It also affects photosynthesis in plant cells (Chen and Han, 2014) and induces reactive oxygen species (ROS) burst, and finally induces cell death (Nawkar et al., 2013). It is reported that a $30 \%$ increase in 
UV-B levels could seriously reduce field crop production in the USA and China (Kakani et al. 2003). However, solar $\mathrm{UV}-\mathrm{B}$ radiation is now considered a light signal which can be perceived by the UV-B Resistance 8 protein (UVR8) and promote its regulation pathway (Yang et al., 2018). The UVR8 interacts with constitutive photomorphogenic 1 (COP1), and regulates the downstream gene expression of elongated hypocotyl 5 (HY5), a transcription factor (Moriconi et al., 2018). However, previous studies have not found any other receptors like UVR8 under enhanced UV-B radiation, and know few things about plant responses to high dose UV-B radiation at the cellular level. Supplying some information on these topics is necessary for us to understand the mechanism of plant response to light.

Actin filaments are a wide spread structure in cells. They contribute to the maintenance of internal architecture of the cell, drive cytoplasmic streaming (the movement of components through the cytosol), and contribute to the process of cell division (Deeks and Hussey, 2001). Actin filaments shift their patterns to respond to certain exogenous factors, including enhanced UV-B radiation (Chen and Han, 2016). Actin filament nucleation and elongation are affected by electrostatics (Crevenna et al., 2013). Previous research has found that actin polymerization is necessary to increase actin filament density and that blocking this increase with actin-disrupting drug latrunculin B leads to enhanced susceptibility of host plants to pathogenic and non-pathogenic bacteria (Henty-Ridilla et al., 2013). Actin cytoskeleton is closely related to nonhost resistance in pepperoncino against certain pathogens, and its polymerization is necessary for the expression of pepper nonhost resistance (Hao et al., 2014). Also, actin filaments play key roles in wheat resistance against Puccinia striiformis (Song et al., 2012). Under salt stress, actin filament dynamics disrupt and trigger an increase in reactive oxygen species levels in Arabidopsis roots (Liu et al., 2012). In Zea mays protodermal root cells, tungsten strongly induces cortical microfilaments which completely depolymerize; intracellular ones appeared highly bundled (Adamakis et al., 2014), while Bisphenol A (BPA) results in actin filaments with rod- and ring-like conformations (Stavropoulou et al., 2018). Under enhanced UV-B radiation, actin filaments form bundles in wheat leaves protoplasts. UV radiation can also induce rearrangement of actin filaments in human cells (Grzanka et al., 2006).

The transition zone of plant roots, which is located between the apical meristem and basal elongation region, has a unique role as the determiner of cell fate and root growth (Baluska et al., 2010). Signaling crosstalk in this region has been shown to determine developmental cell fates as well as mediate rectilinear root growth and the differential growth of tropism. Some evidence shows the root UV-B sensitive protein 1 (RUS1) and RUS2 may have some functions in UV-B signaling in roots through auxin transduction (Yokawa and Baluška, 2015). Moreover, actin filaments are thought to be a crosslinker in certain roles of cell signaling. Therefore, it is valuable information to investigate the change of actin filament dynamics in a key region such as the root.

Until now, there are few reports on how plant roots respond to enhanced UV-B radiation. Here, we focus on actin filament remolding under enhanced UV-B radiation and formation of the bending root. The distribution of actin filaments in the transition zone was tracked after stained with phalloidin-fluorescein isothiocyanate (Ph-FITC). The plasticity of actin filaments in root transition zone and $\mathrm{H}_{2} \mathrm{O}_{2}$ generation were observed. These results will help us understand the possible mechanism of high dose UV-B radiation on induced plant root morphology and provide some information on the UV-B signaling pathway in plants.

\section{Material and Methods}

\subsection{Materials cultivation}

Linyou 2871 (Triticum aestivum L) kernels were supplied by the Wheat Research Institute of Agricultural Sciences in Shanxi Province, China. The seeds were selected and sterilized for $10-15$ min with a $1 \% \mathrm{NaClO}$ solution. The seeds were then washed for $10 \mathrm{~min}$ with running water. Thirty seeds per petri dish were cultured on wet filter paper in a growth chamber at $25^{\circ} \mathrm{C}, 60 \%$ relative humidity, and watered daily. UV-B radiation was applied $8 \mathrm{~h} / \mathrm{d}$ during the light cycle (with $8 \mathrm{~h}$ light and $16 \mathrm{~h}$ dark each day), and the intensity was $10.08 \mathrm{KJ} / \mathrm{m}^{2} / \mathrm{d}$ (Chen and Han, 2014). The root length was determined by a ruler. All experiments were performed with three replications.

\subsection{Fluorescence staining and microscopic observation}

The root tips of wheat seedlings were cut into $2 \mathrm{~mm}$ fragments and collected from the meristem region. 2-6 $\mathrm{mm}$ from to the root tip was collected and prepared as the transition zone. Double fluorescent labeling with 4',6-diamidino-2-phenylindole (DAPI) and Ph-FITC was carried out in wheat root tip cells (Luchetti et al., 2002). The incubation with Ph-FITC $(50 \mu \mathrm{g} / \mathrm{mL})$ was performed at $37^{\circ} \mathrm{C}$ for $40 \mathrm{~min}$, while incubation with DAPI $(100 \mathrm{ng} / \mathrm{mL})$ was at $37^{\circ} \mathrm{C}$ for $10 \mathrm{~min}$. The confocal microscope (Olympus FV1000) was used to observe the results; the object glass was a $\times 60$ magnification oil immersion lens; the picture dimensions were $512 \times 512$ pixels. Pictures were edited with Photoshop CS6.

\subsection{ROS staining in wheat seedlings roots}

An aliquot of H2DCF-DA (Thermo Fisher) was added to all treatments including enhanced UV-B treatment and the control group to obtain a final concentration of $5 \mu \mathrm{M}$. After 20 min, samples were washed three times with PBS to remove excess H2DCF-DA and were immediately visualized using an Olympus FV1000 confocal microscope. Three independent experiments were performed.

\subsection{IAA quantification}

The root tips were homogenized in a cooled mortar with ice-cold $80 \%$ methanol containing $1 \mathrm{mM}$ butylated hydroxytoluene (100 root tips/mL). After centrifugation at 
$12,000 \mathrm{~g}$ for $10 \mathrm{~min}$, samples were passed through a C18 column preconditioned with $80 \%$ methanol at $4^{\circ} \mathrm{C}$. After evaporation of methanol, samples were methylated using trimethylsilyldiazomethane in hexane at $42^{\circ} \mathrm{C}$ for $30 \mathrm{~min}$ and diluted in $25 \mathrm{mM}$ sodium phosphate buffer $(\mathrm{pH}$ 7.2) containing $15 \mathrm{mM} \mathrm{NaCl}$. Quantification of IAA was performed by competitive enzyme-linked immunosorbent assay (IAA immunoassay kit Olchemin).

\subsection{Pharmacological experiment}

IAA was dissolved initially in dimethyl sulfoxide (DMSO) and diluted with water before irradiation. The dilution used was 1000-fold (with a final concentration of $30 \mathrm{nM}$ ) and the control media received an equivalent volume of DMSO. External $\mathrm{H}_{2} \mathrm{O}_{2}$ was also diluted in water and the final concentration was $10 \mathrm{mM}$. For the short-term assay, two day-old seedlings were placed on water incubated for 2h (Tamas et al., 2014).

\subsection{Statistical analyses}

All experiments were carried out across three independent series with three replicates. Data results are expressed as means \pm standard error (SE). Statistical significance was assessed using t-test which was performed using the SPSS 21.0 and Sigma-plot 10.0.

\section{Results}

\subsection{The "bending root" was induced by enhanced $U V-B$ radiation}

After being exposed to enhanced UV-B radiation for $6 \mathrm{~d}$, the growth of wheat seedlings was significantly inhibited (See Figure 1A). The "bending root" in the transition region can be seen after treatment by UV-B radiation after only $2 \mathrm{~d}$ as indicated by the white arrows in the Figure 1B. Compared with the control group (CK), the root length of $6 \mathrm{~d}$ old seedlings in the UV-B treatment group (B) was reduced by almost 55\% (See Figure 1C) and relative elongation rate of the roots were also lessened to nearly $80 \%$ (See Figure 1D).

\subsection{Cell size and the "bending root" located at the transition zone decreased}

DAPI and Ph-FITC were used to stain the nucleus and cell range at the cellular level. The results showed that the "bending root" was located at the transition zone, which is the region between the apical meristem and basal elongation region.

A previous study showed that the region is full of a certain signaling pathway. Here, we found that cell size in the transition region was smaller than the control. This result indicated that enhanced UV-B radiation affected the cell expansion process. As shown in Figure 2A and 2B, the blue color derived from DAPI staining is in the enhanced UV-B treated group. The abnormal morphology indicated that the movement or the distribution of chromosomes in this area was destroyed under UV-B radiation. According to observed results, the cell size was reduced to nearly $65 \%$ compared with the control group (See Figure 2C). As previously shown in Arabidopsis studies, the "root bending" is controlled by auxin signaling. Therefore, it could be that UV-B radiation influenced auxin content. We determined the IAA content in each group, and results showed an increase of $46 \%$ in the UV-B treatment group

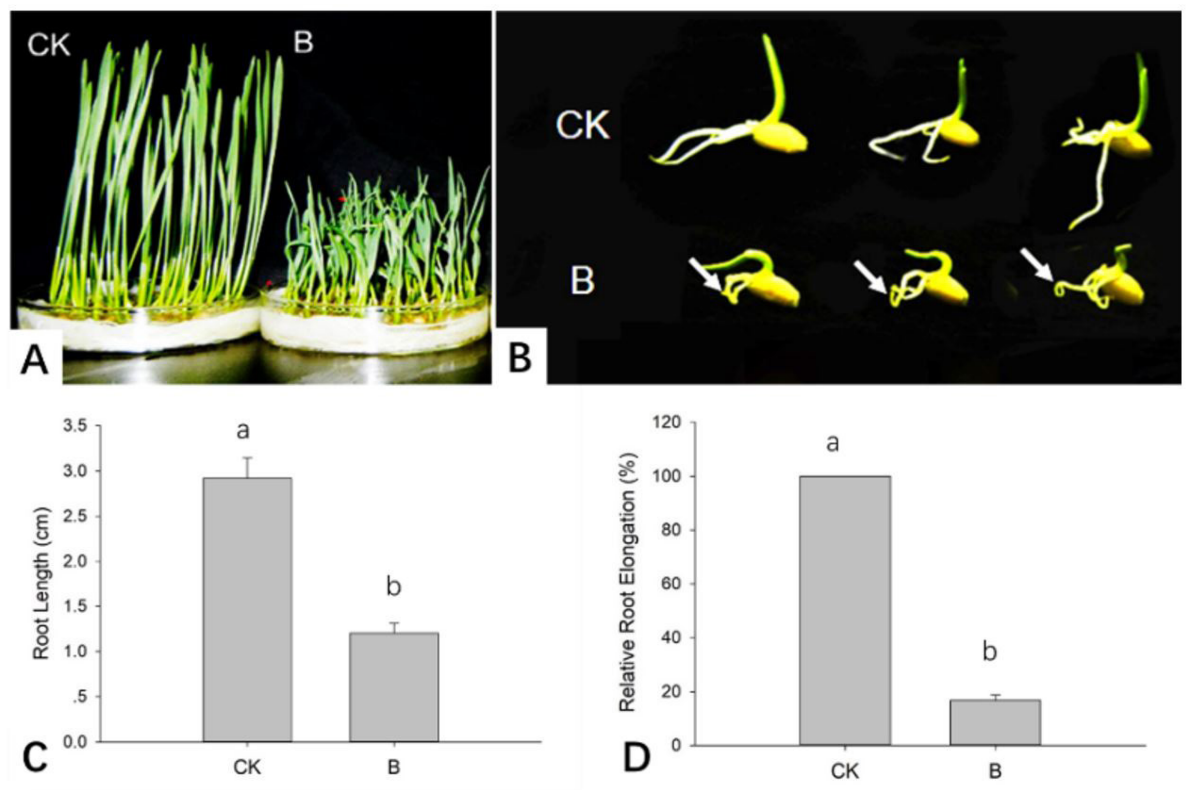

Figure 1. Phenotype of wheat seedlings under enhanced UV-B radiation. UV-B radiation inhibited wheat seedlings growth strongly (A) and induced "bending root" as the white arrow indicated (B). The root length decreased almost $55 \%$ (C) and the relative root elongation lessened nearly $80 \%$ after exposed to enhanced UV-B radiation (D). CK is the control group, $B$ represents UV-B treatment group. Data are means $\pm \mathrm{SE}(\mathrm{n}=3)$. 

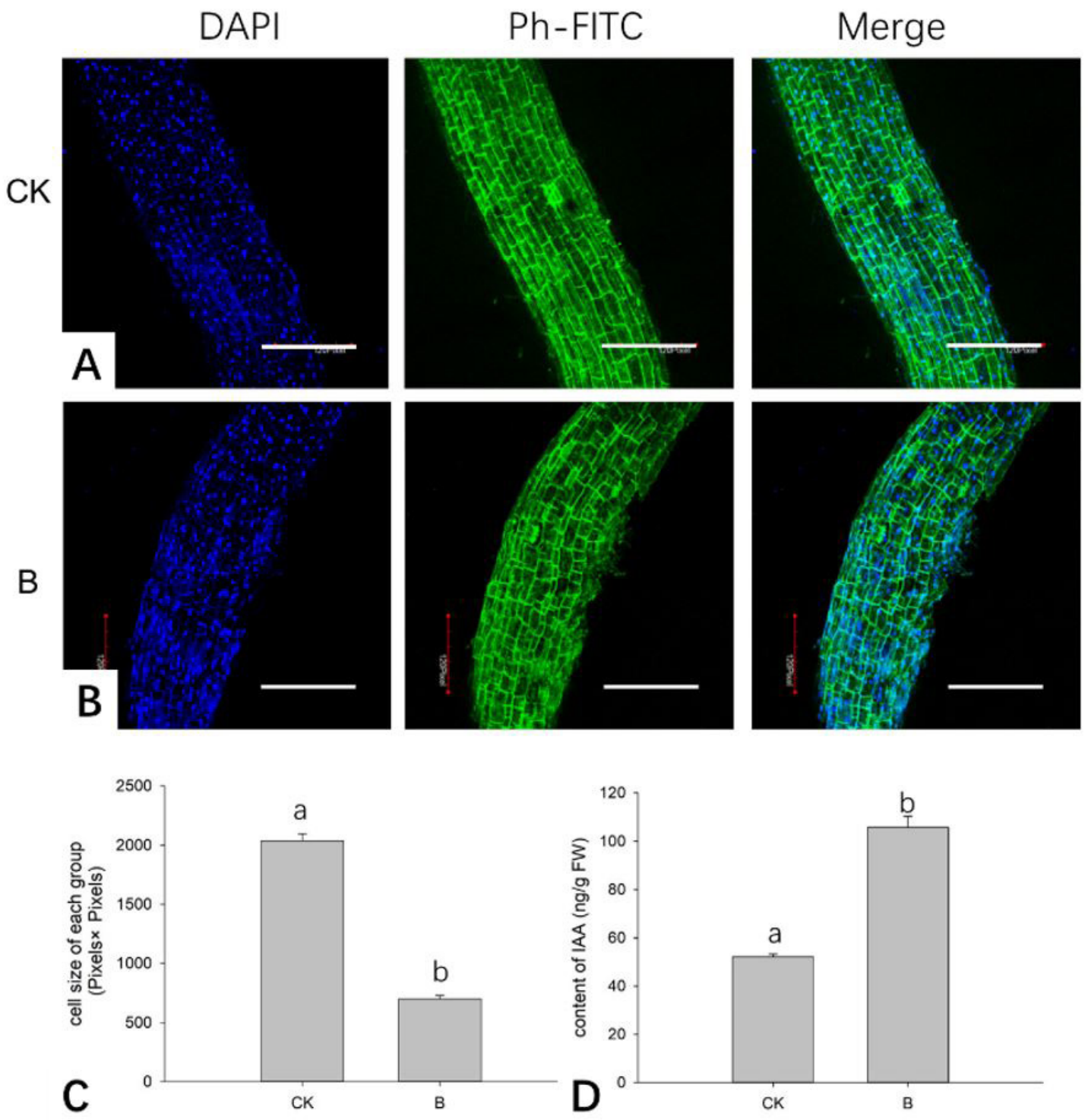

Figure 2. The root cell size is reduced greatly under enhanced UV-B treatment. All the images shown are superimposed stacks of 15 optical sections. Nucleus and actin filaments were stained blue with DAPI and green with Ph-FITC, respectively. The cell size can be shown clearly after stained by Ph-FITC in the control (A) and UV-B treatment group (B). The cell size was calculated which showed it was reduced nearly $65 \%$ under UV-B treatment (C). However, the IAA content was increased almost $46 \%$ (D). Bars in (A) and (B) are $50 \mu \mathrm{m}$. CK is the control group, B represents UV-B treatment group. Data are means $\pm \mathrm{SE}(\mathrm{n}=3)$.

compared to the control (See Figure 2D). These results allow us to infer that UV-B radiation mainly affected the cell expansion due to the increase in IAA level.

\subsection{The ROS burst in the "bending root" region}

As in the "bending root" region, we detected ROS levels in the "bending root." As shown in Figure 3, the fluorescent intensity of the "bending root" region is much higher, almost two-fold, than the control (See Figure 3B). This result indicated that $\mathrm{H}_{2} \mathrm{O}_{2}$ production could be a very important second messenger which activates other signaling pathways or affects other components in the cell. It may possibly be an indicator to show a plant's response to stress.

\subsection{Actin filaments gathered in the "bending root" region}

The cytoskeleton is a key factor in maintaining cell morphology and mitosis. Here, the distribution of actin filaments in different treatments was observed after being stained with Ph-FITC (See Figure 4). The results showed that actin filaments gathered as bundles in the "bending root," but were unconsolidated in the control group. As mentioned above, the cell size was reduced in the 


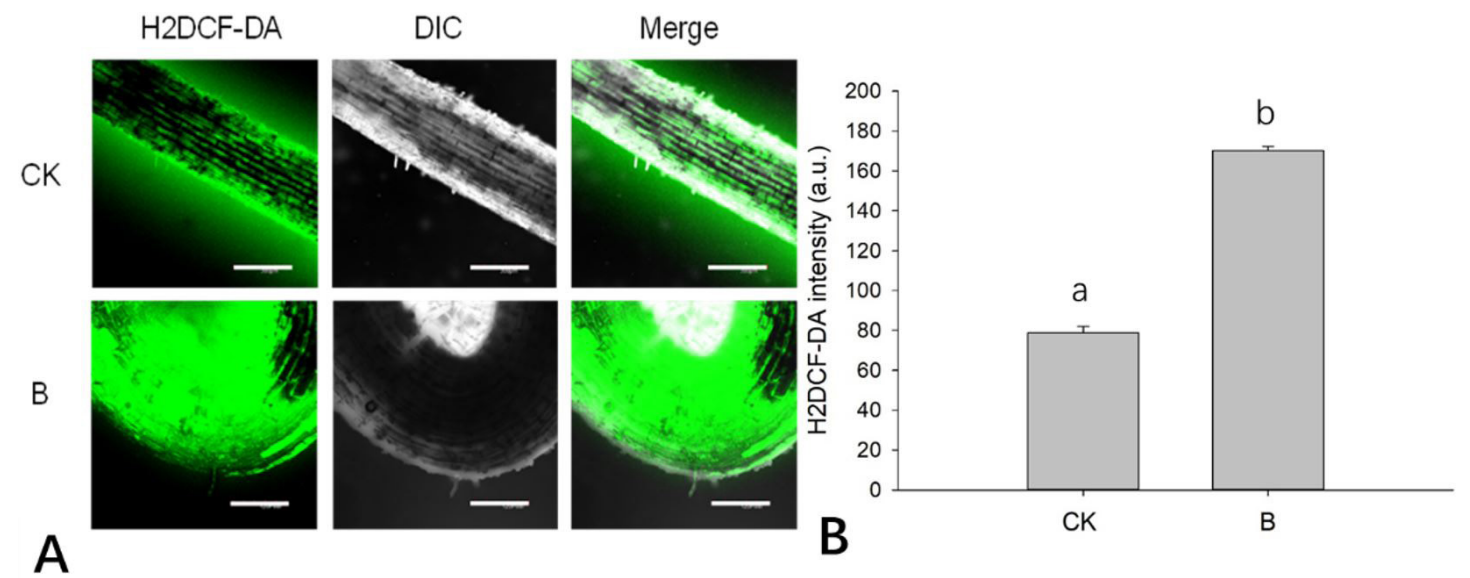

Figure 3. $\mathrm{H}_{2} \mathrm{O}_{2}$ production in the "bending root" region. H2DCF-DA was used for the $\mathrm{H}_{2} \mathrm{O}_{2}$ staining which showed in green (A). Compared with the control, the intensity showed $\mathrm{H}_{2} \mathrm{O}_{2}$ production is highly increased in the wheat root under enhanced UV-B radiation (B). CK is the control group, B represents UV-B treatment group. Data are means \pm SE $(n=3)$.

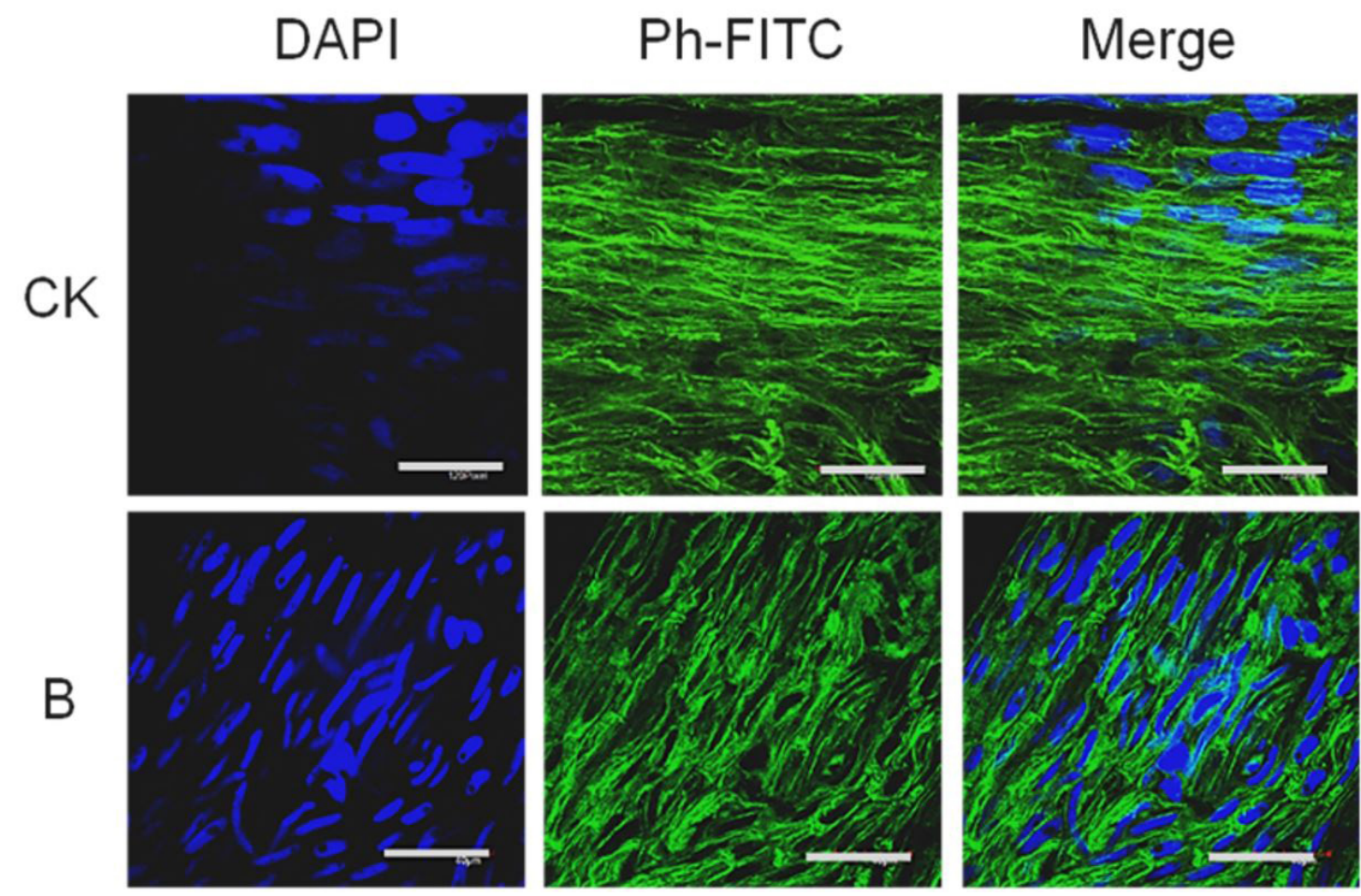

Figure 4. Actin filaments gathered under UV-B treatment. All the images shown are superimposed stacks of 15 optical sections. Nucleus and actin filaments were stained blue with DAPI and green with Ph-FITC, respectively. Compared to the control (CK), the actin filaments were gathered as bundles after exposed to UV-B radiation (B). Bars $=20 \mu \mathrm{m}$.

"bending root" region, potentially as a result of blocked cell growth.

\subsection{External $\mathrm{H}_{2} \mathrm{O}_{2}$ and IAA induced bundling of actin filaments}

A pharmacological experiment was performed to detect the influence of ROS and IAA on the distribution of cellular actin filaments. Two regions of the root were used in the experiment. As shown in the Figure 5, the actin filaments formed actin bundles after being exposed to IAA and $\mathrm{H}_{2} \mathrm{O}_{2}$ either in the transition zone or meristem region of the wheat root. These results indicated that the change in the distribution of cellular actin filaments mainly originated from ROS and IAA content variety, with enhanced UV-B radiation as the original effector. 


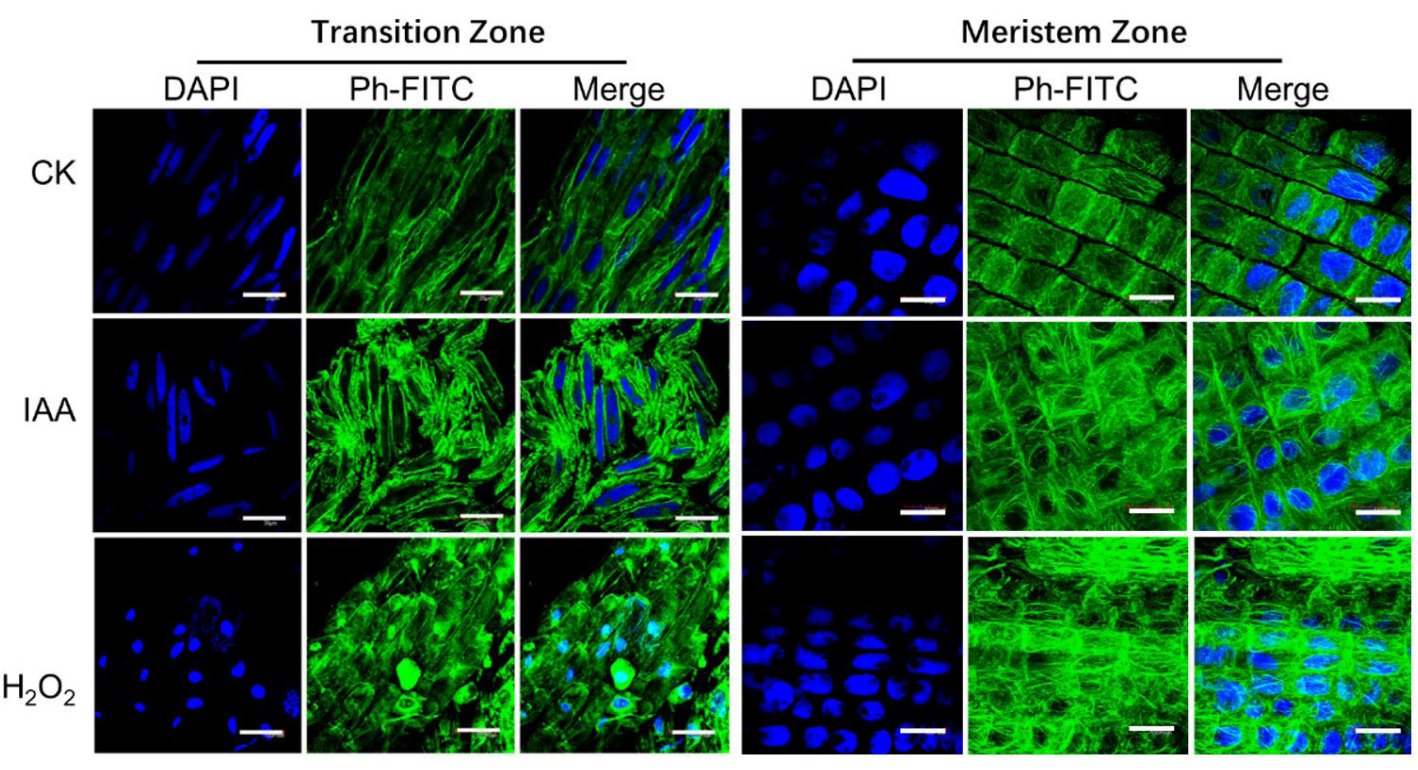

Figure 5. The distribution of actin filaments in wheat root transition zone and meristem zone in the pharmacological experiment. All images shown are superimposed stacks of 15 optical sections. Chromosomes and actin filaments were stained blue with DAPI and green with Ph-FITC, respectively. The actin filaments showed loose form in control (CK) either in the transition zone and meristem region. After applied with external $\mathrm{H}_{2} \mathrm{O}_{2}$ and IAA, the filaments gathered as bundles. Bars $=20 \mu \mathrm{m}$.

\section{Discussion}

UV-B radiation affects plant growth and development in many aspects. Especially causes a reduction in plant biomass. Therefore, it is necessary to understand the impact of this environmental factor on crop plants. Recent studies have focused on the effects of UVR8 signaling pathway and plant morphogenesis (Yang et al., 2018). But there have been fewer studies on the influence of high dose UV-B radiation on plants, especially in crops. We found that high intensity UV-B radiation regulated the dynamics of cellular actin filaments in wheat cells and lead to abnormal mitosis. Other individuals have also been concerned with the yield of crop plants exposed to enhanced UV-B radiation, which have resulted in fewer studies of the effects of UV-B radiation at the cellular level. Our results here supply this missing information on cellular processes and their response to UV-B radiation.

There is doubt surrounding how plant roots can sense light signals if the roots are underground in darkness. One possible explanation for this anomaly is that the surface of the ground is loose and light can penetrate to the root. More importantly, some photoreceptors including UVR8 are found not only in aerial parts of plants, but also in their roots (Briggs, 2014). People proposed that light is sensed by the roots directly under natural soil conditions. Specifically, light may pass through the soil to the root or may be conducted through vascular tissue to the root. Recently, it was reported that light was channeled through the stem to the roots, where it activated the red-light photoreceptor phytochrome (Lee et al., 2016), consistent with the hypothesis that the aboveground light environment is monitored by the roots by stem-piped light under natural conditions. UVR8 is expressed in roots, which indicated plant roots could sense the UV-B light as the way mentioned above. This made our study full of meaningful.

In this study, the wheat root was exposed to UV-B light with any cover and formed a "bending root." UV-B radiation induced ROS production which damaged the root cell pectin and formed pectin-containing vesicles through endocytosis (Baluška and Mancuso, 2013). In this respect, the root apex transition zone may be very responsive to UV-B due to the high rate of pectin recycling found precisely in this root apex region (Baluška and Mancuso, 2013). In this zone, root-specific UV-B sensing proteins RUS1 and RUS2 are expressed and, more importantly, control polar auxin transport. Cellular vesicle transport depends on the distribution of actin filaments. Our results showed that actin filaments gathered into bundles under UV-B radiation. Which indicated such bundle structure affected the transport process of pectin-containing vesicles. All these observations restricted cell growth since the precondition of growth is the cell structure is normal.

The phytohormonal control of actin filament organization by auxin plays a key role in plant morphogenesis, which determines growth and differentiation of various plant organs (Blume et al., 2012). IAA suppressed growth of Arabidopsis roots not by affecting cell division but by reducing the length of the elongation zone. One possible reason is that IAA may have enhanced the formation of actin filaments bundles which inhibited cell elongation (Rahman et al., 2007) as shown in this paper. Recent studies have confirmed that UV-B radiation-induced root bending occurs through a flavonoid-mediated phototropic 


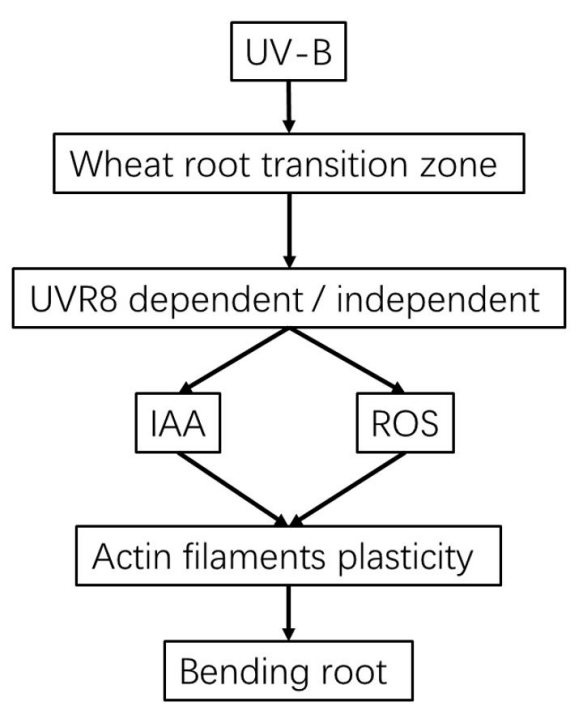

Figure 6. A diagram of the wheat root response the UV-B radiation. Wheat root can sense the UV-B radiation through a UVR8 dependent/independent pathway. This would induce ROS burst and increased IAA contents, enhanced the actin filaments bundles formation and performed as "bending root".

response to UV-B radiation in Arabidopsis (Wan et al., 2018). They also found that UV-B radiation increased the distribution of auxin on the nonradiated side of the root tips, promoting growth and causing root bending. Our results also showed that IAA content increased which may have led to the bending root formation in wheat. However, the ultimate reason for the bending root formation could be due to the remolding of actin filaments.

As shown in Figure 6, wheat roots can sense UV-B radiation through an UVR8 dependent/independent pathway. This induced ROS burst and increased IAA content, which enhanced actin filament bundle formation and formation of the "bending root".

\section{Conclusion}

Here we reported the response of wheat roots exposed to enhanced UV-B radiation. Our results showed that UV-B radiation decreased seedling growth and induced "bending root" formation. In the transition zone of the wheat root, ROS burst and the IAA content increased, which caused actin filaments to gather as bundles. These bundled actin filaments could be a key factor in cell expansion or mitosis. Together, these results confirmed that the reason enhanced UV-B radiation inhibited plant growth could be due to the altered distribution of actin filaments in plant cells.

\section{Acknowledgements}

This work was supported by JRK2018003 from YangZhou University and the Natural Science Foundation of China under Grant No. 31900251.

\section{References}

ADAMAKIS, I.D., PANTERIS, E. and ELEFTHERIOU, E.P., 2014. The nitrate reductase inhibitor, tungsten, disrupts actin microfilaments in Zea mays L. Protoplasma, vol. 251, no. 3, pp. 567-574. http://dx.doi.org/10.1007/s00709-013-0556-1. PMid:24091895.

BALUŠKA, F. and MANCUSO, S., 2013. Root apex transition zone as oscillatory zone. Frontiers of Plant Science, vol. 4, pp. 354. http://dx.doi.org/10.3389/fpls.2013.00354. PMid:24106493.

BALUSKA, F., MANCUSO, S., VOLKMANN, D. and BARLOW, P.W., 2010. Root apex transition zone: a signalling-response nexus in the root. Trends in Plant Science, vol. 15, no. 7, pp. 402-408. http://dx.doi.org/10.1016/j.tplants.2010.04.007. PMid:20621671.

BLUME, Y.B., KRASYLENKO, Y.A. and YEMETS, A.I., 2012. Effects of phytohormones on the cytoskeleton of the plant cell. Russian Journal of Plant Physiology: a Comprehensive Russian Journal on Modern Phytophysiology, vol. 59, no. 4, pp. 515-529. http://dx.doi.org/10.1134/S1021443712040036.

BRIGGS, W.R., 2014. Phototropism: some history, some puzzles, and a look ahead. Plant Physiology, vol. 164, no. 1, pp. 13-23. http://dx.doi.org/10.1104/pp.113.230573. PMid:24399823.

BROSCHE, M. and STRID, A., 2003. Molecular events following perception of ultraviolet-B radiation by plants. Physiologia Plantarum, vol. 117, no. 1, pp. 1-10. http://dx.doi.org/10.1034/ j.1399-3054.2003.1170101.x.

CHEN, H. and HAN, R., 2014. He-Ne laser treatment improves the photosynthetic efficiency of wheat exposed to enhanced UV-B radiation. Laser Physics, vol. 24, no. 10, pp. 105602. http://dx.doi. org/10.1088/1054-660X/24/10/105602.

CHEN, H. and HAN, R., 2016. Characterization of actin filament dynamics during mitosis in wheat protoplasts under UV-B radiation. Scientific Reports, vol. 6, no. 1, pp. 20115. http://dx.doi. org/10.1038/srep20115. PMid:26823006.

CREVENNA, A.H., NAREDI-RAINER, N., SCHONICHEN, A., DZUBIELLA, J., BARBER, D.L., LAMB, D.C. and WEDLICHSOLDNER, R., 2013. Electrostatics control actin filament nucleation and elongation kinetics. The Journal of Biological Chemistry, vol. 288, no. 17, pp. 12102-12113. http://dx.doi.org/10.1074/jbc. M113.456327. PMid:23486468.

DEEKS, M. J. and HUSSEY P. J., 2001. Plant actin biology. New Jersey: John Wiley \& Sons, Inc., pp. 1-9.

GRZANKA, D., DOMANIEWSKI, J., GRZANKA, A. and ZURYN, A., 2006. Ultraviolet radiation (UV) induces reorganization of actin cytoskeleton in CHOAA8 cells. Neoplasma, vol. 53, no. 4, pp. 328-332. PMid:16830061.

HAO, X., LI, H., HUA, Y., YU, K., WALTER, M., QI, T., ZHANG, B. and MA, Q., 2014. Actin dynamic polymerization is required for the expression of nonhost resistance in pepper against Blumeria graminis f. sp. Tritici. Physiological and Molecular Plant Pathology, vol. 86, pp. 64-72. http://dx.doi.org/10.1016/j. pmpp.2014.04.001.

HENTY-RIDILLA, J.L., SHIMONO, M., LI, J., CHANG, J.H., DAY, B. and STAIGER, C.J., 2013. The plant actin cytoskeleton responds to signals from microbe-associated molecular patterns. PLoS Pathogens, vol. 9, no. 4, pp. e1003290. http://dx.doi. org/10.1371/journal.ppat.1003290. PMid:23593000.

JENKINS, G.I., 2017. Photomorphogenic responses to ultraviolet-B light. Plant, Cell \& Environment, vol. 40, no. 11, pp. 2544-2557. http://dx.doi.org/10.1111/pce.12934. PMid:28183154. 
KAKANI, V.G., REDDY, K.R., ZHAO, D. and SAILAJA, K., 2003. Field crop responses to ultraviolet-B radiation: a review. Agricultural and Forest Meteorology, vol. 120, no. 1-4, pp. 191218. http://dx.doi.org/10.1016/j.agrformet.2003.08.015.

LEE, H.J., HA, J.H., KIM, S.G., CHOI, H.K., KIM, Z.H., HAN, Y.J., KIM, J.I., OH, Y., FRAGOSO, V., SHIN, K., HYEON, T., CHOI, H.G., OH, K.H., BALDWIN, I.T. and PARK, C.M., 2016. Stem-piped light activates phytochrome B to trigger light responses in Arabidopsis thaliana roots. Science Signaling, vol. 9, no. 452, pp. ra106-ra106. http://dx.doi.org/10.1126/scisignal. aaf6530. PMid:27803284.

LIU, S.G., ZHU, D.Z., CHEN, G.H., GAO, X.Q. and ZHANG, X.S., 2012. Disrupted actin dynamics trigger an increment in the reactive oxygen species levels in the Arabidopsis root under salt stress. Plant Cell Reports, vol. 31, no. 7, pp. 1219-1226. http:// dx.doi.org/10.1007/s00299-012-1242-z. PMid:22383108.

LUCHETTI, F., BURATTINI, S., FERRI, P., PAPA, S. and FALCIERI, E., 2002. Actin involvement in apoptotic chromatin changes of hemopoietic cells undergoing hyperthermia. Apoptosis, vol. 7, no. 2, pp. 143-152. http://dx.doi.org/10.1023/A:1014362415047. PMid:11865198.

MORICONI, V., BINKERT, M., COSTIGLIOLO, C., SELLARO, R., ULM, R. and CASAL, J.J., 2018. Perception of Sunflecks by the UV-B Photoreceptor UV Resistance Locus 8. Plant Physiology, vol. 177, no. 1, pp. 75-81. http://dx.doi.org/10.1104/pp.18.00048. PMid:29530938.

NAWKAR, G.M., MAIBAM, P., PARK, J.H., SAHI, V.P., LEE, S.Y. and KANG, C.H., 2013. UV-induced cell death in plants. International Journal of Molecular Sciences, vol. 14, no. 1, pp. 1608-1628. http://dx.doi.org/10.3390/ijms14011608. PMid:23344059.

RAHMAN, A., BANNIGAN, A., SULAMAN, W., PECHTER, P., BLANCAFLOR, E.B. and BASKIN, T.I., 2007. Auxin, actin and growth of the Arabidopsis thaliana primary root. The Plant
Journal, vol. 50, no. 3, pp. 514-528. http://dx.doi.org/10.1111/ j.1365-313X.2007.03068.x. PMid:17419848.

SONG, X., MA, Q., HAO, X. and LI, H., 2012. Roles of the actin cytoskeleton and an actin-binding protein in wheat resistance against Puccinia striiformis f. sp. tritici. Protoplasma, vol. 249, no. 1, pp. 99-106. http://dx.doi.org/10.1007/s00709-011-0265-6. PMid:21298301.

STAVROPOULOU, K., ADAMAKIS, I.S., PANTERIS, E., ARSENI, E.M. and ELEFTHERIOU, E.P., 2018. Disruption of actin filaments in Zea mays by bisphenol A depends on their crosstalk with microtubules. Chemosphere, vol. 195, pp. 653-665. http:// dx.doi.org/10.1016/j.chemosphere.2017.12.099. PMid:29287273.

TAMAS, L., MISTRIK, I., ALEMAYEHU, A., ZELINOVA, V., BOCOVA, B. and HUTTOVA, J., 2014. Salicylic acid alleviates cadmium-induced stress responses through the inhibition of Cdinduced auxin-mediated reactive oxygen species production in barley root tips. Journal of Plant Physiology, vol. 173, pp. 1-8. http://dx.doi.org/10.1016/j.jplph.2014.08.018. PMid:25462072.

WAN, J., ZHANG, P., WANG, R., SUN, L., WANG, W., ZHOU, H. and XU, J., 2018. UV-B radiation induces root bending through the flavonoid-mediated auxin pathway in Arabidopsis. Frontiers of Plant Science, vol. 9, pp. 618. http://dx.doi.org/10.3389/ fpls.2018.00618. PMid:29868074.

YANG, Y., LIANG, T., ZHANG, L., SHAO, K., GU, X., SHANG, R., SHI, N., LI, X., ZHANG, P. and LIU, H., 2018. UVR8 interacts with WRKY36 to regulate HY5 transcription and hypocotyl elongation in Arabidopsis. Nature Plants, vol. 4, no. 2, pp. 98-107. http://dx.doi.org/10.1038/s41477-017-0099-0. PMid:29379156.

YOKAWA, K. and BALUŠKA, F., 2015. Pectins, ROS homeostasis and UV-B responses in plant roots. Phytochemistry, vol. 112, pp. 80-83. http://dx.doi.org/10.1016/j.phytochem.2014.08.016. PMid:25220496. 